\title{
Selected problems of risers machining
}

\author{
Wybrane problemy obróbki riserów
}

\author{
EDWARD MIKO \\ ŁUKASZ NOWAKOWSKI \\ MARIAN SZCZERBA \\ PIOTR KRAWCZYK \\ MICHAŁ KOPANIA *
}

\begin{abstract}
Presented are the risers machining process and the results of measurement of selected errors of their execution. Risers are a system of pipes used to connect the outlet of the eruption head with the oil platform. The biggest problem during risers machining is their length, which in the described example is $15,140 \mathrm{~mm}$.
\end{abstract}

KEYWORDS: riser, turning, drilling long holes, boring long holes

There are many research projects around the world regarding various aspects of the deep hole machining process, i.e.:

- impact of the tool construction on the dimensional accuracy of the drilled holes [1] and the integrity of the surface after drilling and boring of deep holes [2],

- thermal deformation of the workpiece during drilling deep holes [3],

- impact of the tool geometry on chip evacuation [4] and the dynamics of the coolant flow to improve the cooling effect when drilling deep holes and flushing the chips [5],

- optimization of the design of the deep hole drilling tool [6].

The article describes in a simplified way the problems that occurred during technological trials of processing risers. The tests were carried out at CELSA Huta Ostrowiec in Ostrowiec Świętokrzyski. The semi-finished entry angle for the machining process was free rod with diameter $\varnothing \sim 370$ $\mathrm{mm}$, length $16140 \mathrm{~mm}$ and weight $10328 \mathrm{~kg}$.

The main problem associated with the length of the produced risers is the drilling of long holes and the uneven heating of the workpiece during the turning process, which is the reason for the pipe to bend when removing subsequent layers of machining allowance.

\footnotetext{
* Dr hab. inż. Edward Miko prof. PŚk (emiko@tu.kielce.pl), dr inż. Łukasz Nowakowski (lukasn@tu.kielce.pl) - Katedra Technologii Mechanicznej i Metrologii, Politechnika Świętokrzyska; mgr inż. Marian Szczerba (mszczerba@celsaho.com), mgr inż. Piotr Krawczyk (krawczyk@celsaho.com), mgr inż. Michał Kopania (kopania@celsaho.com)-Wydział Obróbki Mechanicznej CELSA Huta Ostrowiec
}

\section{Production process of risers}

The first stage of production of risers was the execution in CELSA Hutta Ostrowiec using the forging method in the F22 grade, weight $\sim 10328 \mathrm{~kg}$, in the form of a bar with a diameter of $\varnothing \sim 370 \mathrm{~mm}$ and length $16140 \mathrm{~mm}$. Overall dimensions forgings have machining allowances on the diameter of $25.6 \mathrm{~mm}$ to $110 \mathrm{~mm}$ and length $-1270 \mathrm{~mm}$ (material for destructive testing after heat treatment: $\sim 400$ $\mathrm{mm}$, material for thermal barriers and technological surplus: $300 \mathrm{~mm}$, material for fastening - in a special holder in a vertical furnace during heat treatment: $570 \mathrm{~mm}$ ).

After the forging and the initial heat treatment, the riser was pre-machined and bored, and the axial hole was bored. Then a qualitative heat treatment was performed in a vertical gas furnace. The heat-treated riser fabric had to meet very high strength requirements: tensile strength $R m \geq$ $670 \mathrm{MPa}$, yield strength $R e \geq 550 \mathrm{MPa}$, sample elongation A4 $\geq 40 \%$, tapering rate $\geq 40 \%$, impact strength $K V \geq 100 \mathrm{~J}$ at temperature $-40^{\circ} \mathrm{C}$.

In addition, the pipe material was subjected to nondestructive tests: ultrasonic (UT) and magnetic (MT) to confirm the high requirements of steel cleanliness specified in the material specifications. After receiving positive results of destructive and non-destructive tests, it was possible to proceed to the final machining (turning outer diameters and opening the hole) and to carry out a measurement report on geometrical quantities of the product.

\section{Turning raw forging}

The turning of the raw tube forging took place on a heavy TCH160 type lathe. The rolling operations of the nipple (circumferential strips on the outer diameter of $\sim 120 \mathrm{~mm}$, used to support the forgings of the holders) were made using a centering sleeve, allowing for precise axial alignment of the workpiece and support with roller supports.

The made tube should have a roundness deviation not exceeding $0.04 \mathrm{~mm}$, radial run-out maximum $0.02 \mathrm{~mm}$ and a surface roughness $R a<1.25 \mu \mathrm{m}$. During turning, the forging was supported by three roller rests. The turning parameters, depending on the cross-section of the cutting layer, were 
within the following limits: cutting speed $v_{c}=40 \div 60 \mathrm{~m} / \mathrm{min}$, feed $f=0.4 \div 1.0 \mathrm{~mm} / \mathrm{rev}$.

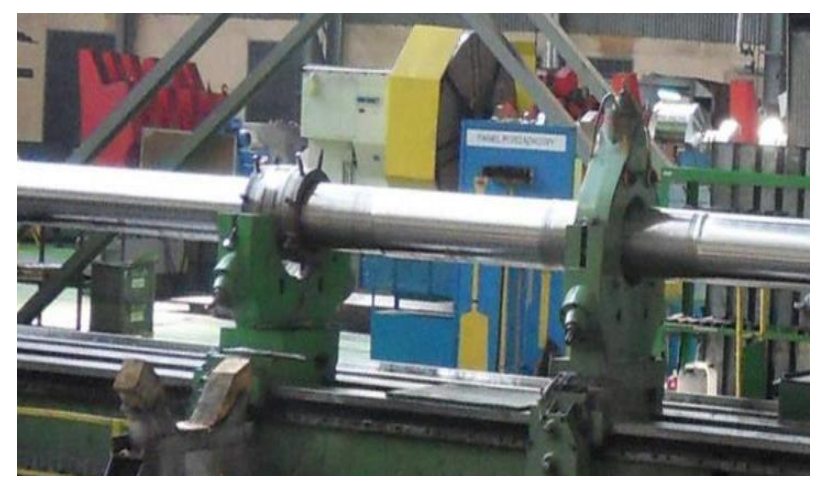

Fig. 1. Method of supporting the riser during the turning process

\section{Drilling hole $\varnothing 150 \mathrm{~mm}$ and boring at $\varnothing 175 \mathrm{~mm}$}

Drilling of the hole $\varnothing 150$ and successive boring was performed on a deep hole drilling machine type KŻ 1920 , using special drilling and boring heads of their own design, mounted on a drilling rod (STS system, fig. 2), working at the cutting speed $v_{c}=60 \mathrm{~m} / \mathrm{min}$ and feedrate $v_{f}=9 \div 12$ $\mathrm{mm} / \mathrm{min}$. The changes in pressure on the oil supply to the head were in the range of $0.1 \div 6.0$ bar and were dependent on the head's construction, hole length, bar and head diameter, cutting data and the type of chips. The oil flow 200, 400, $600 \mathrm{l} / \mathrm{min}$ - was adjustable. Before each boring process, pilot holes were made, the shape and dimensions of which are shown in fig. 3 and in the table. AND.

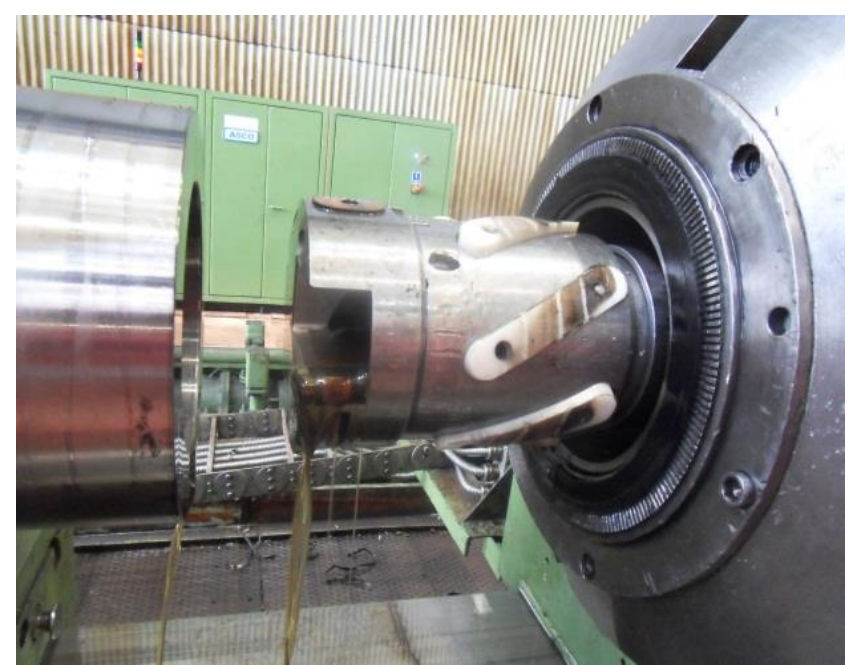

Fig. 2. Tool for drilling holes in risers

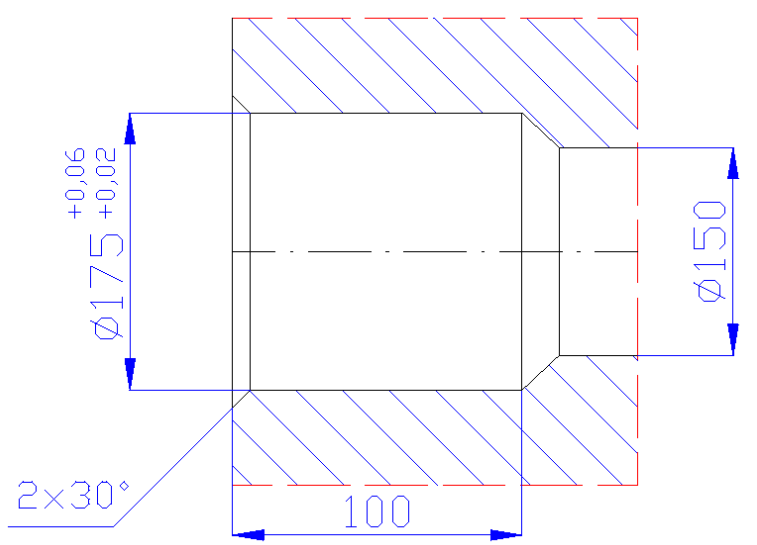

Fig. 3. Example pilot hole made for the hole boring operation $\varnothing 150$ $\mathrm{mm}$ to $\varnothing 175 \mathrm{~mm}$
TABLE I. Dimensions of pilot holes

\begin{tabular}{|l|c|c|c|c|c|}
\hline \multicolumn{1}{|c|}{ Nr } & 1 & 2 & 3 & 4 & 5 \\
\hline $\begin{array}{l}\text { Diameter of the } \\
\text { reamed hole, mm }\end{array}$ & 150 & 175 & 200 & 210 & 219,4 \\
\hline $\begin{array}{l}\text { Diameter of the pilot } \\
\text { hole, mm }\end{array}$ & 175 & 200 & 210 & 219,4 & - \\
\hline Depth, mm & \multicolumn{5}{c|}{100} \\
\hline $\begin{array}{r}+0,06 \\
+0,02\end{array}$ & $\begin{array}{c}- \\
-\end{array}$ \\
\hline Tolerance mm & \multicolumn{5}{|c|}{} \\
\hline
\end{tabular}

During drilling of the holes there were problems with the removal of chips through the holes of the drill rods (Fig. 4). The difference in wall thickness in individual cross-sections of risers did not exceed $3 \mathrm{~mm}$ over the entire length of the hole - after drilling operations.

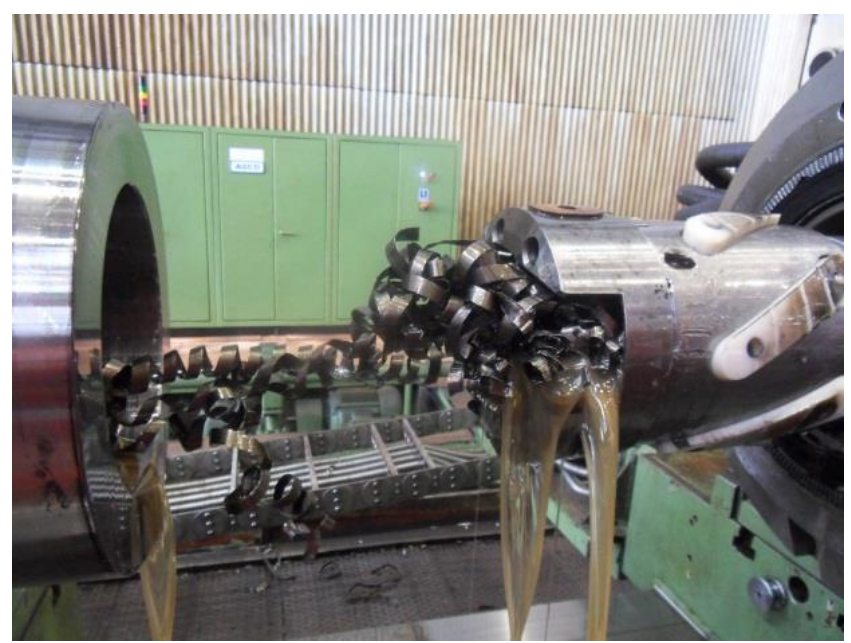

Fig. 4. Form of chips making their removal difficult

\section{Thermal treatment}

In order to minimize the error in the straightness of the workpiece, the heat treatment of the risers was already carried out in the vertical furnace at the stage of thermal improvement, where a universal disc sling was used to suspend the pipes. It allowed to hook two or four pieces at once, for example: riders, shafts or rods.

Two opposite holes in the plate were used - one to suspend the riser, and the other - to the counterweight. It was impossible to suspend one pipe due to the lack of a suitable handle.

After the heat treatment of the pipe, its elongation was increased by $\sim 15 \mathrm{~mm}$ on a length of $10746 \mathrm{~mm}$ and a straightness error of $\sim 15 \mathrm{~mm} / 15,000 \mathrm{~mm}$.

The pipe was subjected to a straightening process and thermal treatment was repeated. The rectilinearity of the pipe was again measured - the straightness error on the entire length of the pipe was $7 \mathrm{~mm}$.

After heat treatment, the hardness of the tube was measured with a EQOTIP 550 hardness tester using the Leeba dynamic method at points as shown in the diagram in fig. 5. The results of the hardness measurements are presented in tab. II.

Based on the analysis of the measurement results, it was found that the difference in the hardness of the pipe along the angular positions G1, G2, G3, G4 and distance was within $47 \div 54 \mathrm{HB}$, and in particular cross-sections contained in the range of $7 \div 13 \mathrm{HB}$.

Then, the next stage of machining was started. 


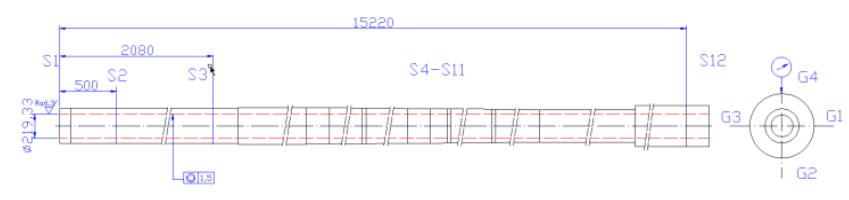

Fig. 5. Riser measurement scheme

TABLE II. Results of shaft hardness measurements after heat treatment

\begin{tabular}{|c|c|c|c|c|c|}
\hline \multirow[b]{2}{*}{$\begin{array}{c}\text { Distance, } \\
\mathrm{mm}\end{array}$} & \multicolumn{4}{|c|}{ Hardness, HB } & \multirow[b]{2}{*}{$\Delta$} \\
\hline & G1 & G2 & G3 & G4 & \\
\hline 0 & 199 & 194 & 199 & 201 & 7 \\
\hline 500 & 200 & 199 & 201 & 194 & 7 \\
\hline 2100 & 226 & 221 & 217 & 226 & 9 \\
\hline 3700 & 216 & 218 & 220 & 211 & 9 \\
\hline 5300 & 200 & 208 & 199 & 195 & 13 \\
\hline 6900 & 204 & 197 & 205 & 203 & 8 \\
\hline 8500 & 190 & 199 & 196 & 198 & 9 \\
\hline 10100 & 206 & 203 & 212 & 215 & 12 \\
\hline 11700 & 228 & 221 & 219 & 215 & 13 \\
\hline 13300 & 183 & 189 & 188 & 190 & 7 \\
\hline 14900 & 233 & 221 & 231 & 233 & 12 \\
\hline 15440 & 237 & 238 & 235 & 244 & 9 \\
\hline$\Delta$ & 54 & 49 & 47 & 54 & \\
\hline
\end{tabular}

External turning and boring turning on: $\varnothing 190 \mathrm{~mm}, \varnothing$ $210 \mathrm{~mm}, \varnothing 219,4 \mathrm{~mm}$

The machining was started by calibrating the "straightening out" of the outer surface of the pipe by means of a connection with a suitably adjusted axis (fig. 1). The distance between the axes and a part of the shaft length is achieved due to the eccentric fixing of the shaft in the centering sleeve with the help of adjustment bolts. Then, from the moved axis, a "tube" (fig. 3, tab. I, tab. II) was made to insert the boring head and the boring was started at $\varnothing 190 \mathrm{~mm}$, with the cutting parameters: $v_{f}=8 \div 12 \mathrm{~mm} / \mathrm{min}$ and $v_{\mathrm{c}}=60 \mathrm{~m} / \mathrm{min}$.

Drilling and hole boring is carried out using the STS method, i.e. one-shot method, in which the flushing oil is fed through a gap between the machined hole and the surface of the drilling rod. The chips are discharged through the hole of the rod. During the boring, the pipe was supported by five steadies.

The problem of difficult chip breaking from the material from which the pipe was made, was solved by reducing the feed. In this way, relatively regular and easy-to-rinse chips were obtained. The use of a higher feed resulted in the formation of hard-breakable shavings, which blocked the drill rod and prevented further processing.

Obtained dimensions of the hole diameter $\varnothing 190 \mathrm{~mm}$ at the entrance are $\varnothing 190.08 \mathrm{~mm}$, and at the exit $-\varnothing 190.14$ $\mathrm{mm}$, the diameter of the mole was $\varnothing 190+0.05 /+0.03$.

Then the turning operations were prepared, preparing the boring pipe at $\varnothing 210 \mathrm{~mm}$ and $\varnothing 219.4 \mathrm{~mm}$ (tab. I), and a pipe meeting the requirements shown in fig. 5 was obtained. Measurements of the diameters at the beginning and end of the hole to be removed from $\varnothing 190 \mathrm{~mm}$ to $\varnothing 210 \mathrm{~mm}$ showed that the entry hole diameter was $0.04 \mathrm{~mm}$ higher than at the output (input $\varnothing 210.08 \mathrm{~mm}$, output $\varnothing 210.24$ $\mathrm{mm}$ ). During mechanical machining, the thin walls of the pipe, communes $=19.56 \mathrm{~mm}$, were warming up, which is why it was necessary to use very abundant cooling.
TABLE III. Results of measurements of the riser wall thickness after final capping to $\varnothing 219,4 \mathrm{~mm}$

\begin{tabular}{|c|c|c|c|c|c|c|}
\hline \multirow{2}{*}{$\begin{array}{c}\text { Distance } \\
\mathrm{mm}\end{array}$} & \multicolumn{3}{|c|}{$\begin{array}{c}\text { Wall thickness, } \\
\mathrm{mm}\end{array}$} & \multicolumn{3}{c|}{$\begin{array}{c}\text { Difference of wall thick- } \\
\text { ness, mm }\end{array}$} \\
\cline { 2 - 7 } & G1 & G2 & G3 & G4 & $\begin{array}{c}\text { G1 - } \\
\text { G3 }\end{array}$ & G2 - G4 \\
\hline 50 & 65,1 & 65,1 & 65,0 & 65,1 & 0,1 & 0,0 \\
\hline 1520 & 27,4 & 27,2 & 27,2 & 27,2 & 0,2 & 0,0 \\
\hline 3040 & 32,4 & 32,1 & 31,8 & 32,1 & 0,6 & 0,0 \\
\hline 4560 & 38,1 & 37,6 & 37,3 & 37,5 & 0,8 & 0,1 \\
\hline 6080 & 42,6 & 42,3 & 41,6 & 42,2 & 1,0 & 0,1 \\
\hline 7600 & 43,9 & 43,6 & 43,1 & 43,4 & 0,8 & 0,2 \\
\hline 9120 & 47,6 & 47,3 & 46,8 & 47,1 & 0,8 & 0,2 \\
\hline 10640 & 42,0 & 41,7 & 41,2 & 41,5 & 0,8 & 0,2 \\
\hline 12160 & 42,0 & 41,8 & 41,6 & 41,6 & 0,4 & 0,2 \\
\hline 13680 & 42,4 & 42,4 & 42,3 & 42,3 & 0,1 & 0,1 \\
\hline 15200 & 42,4 & 42,4 & 42,4 & 42,3 & 0,0 & 0,1 \\
\hline
\end{tabular}

\section{Description of the method of wall thickness measurement}

Measurements of wall thickness of risers after each turning, drilling and boring operation were carried out using ultrasonic thickness gauges, with a measuring accuracy of $0.1 \mathrm{~mm}$. The wall thickness measuring points were prepared by turning the outside diameter of the $30 \mathrm{~mm}$ wide strips, maintaining the transverse runout maximum $0.05 \mathrm{~mm}$ and the surface roughness $R a=1.25 \mu \mathrm{m}$. Preservation of the same position of the measuring points on subsequent measurements allowed to follow changes in the rectilinearity of the hole.

\section{Conclusions}

- Differences in pipe surface hardness indicate the place and direction of the pipe's curvature when removing the subsequent surplus layers. In place of areas with higher hardness, the curvature of the pipe was convex (beating outwards). One should strive to achieve the same hardness on the entire surface of the pipe.

- The pipe straightness error after heat treatment should not exceed $4 \mathrm{~mm}$. Larger curvature of pipes considerably extends the machining time, and in exceptional cases there may be a lack of machining allowance.

- It should be noted that the pipe is significantly elongated after the heat treatment and that a sufficiently large portion of material is placed on the pipe end faces.

- The problem of poor drilling performance and hole boring in materials that give breakable chips are still to be solved. The use of low drilling and boring parameters allowed the chips to flow out with the oil, but at the cost of extending the processing time.

- Large influence on the straightness of the pipe after machining has the number of pipe supports used during machining. When processing pipes with a length of $\sim 16 \mathrm{~m}$, it is advisable to use five steadies. A smaller number of steadies contributes to a greater cross-section of the pipes, and a larger number of stops keeps them very difficult during machining due to the necessity of frequent relocation.

\section{REFERENCES}

1. Nowakowski Ł., Miko E., Skrzyniarz M. „Ocena dokładności wymiarowo-kształtowej otworów wierconych wiertłami składanymi”. Mechanik. 8-9 (2016): pp. 1200-1201.

2. Huang Zhang, Xingquan Shen, Arixin Bo, Yaoming Li, Haife Zhan, Yuantong Gu. "A multiscale evaluation of the surface integrity in boring trepanning association deep hole drilling". International Journal of Machine Tools and Manufacture. 123 (2017): pp. 48-56. 
3. Biermann D., lovkov I. "Investigations on the thermal workpiece distortion in MQL deep hole drilling of an aluminium cast alloy". CIRP Annals - Manufacturing Technology. 64 (2015) pp. 8588.

4. Tnay G.L., Wan S., Woon K.S., Yeo S.H. "The effects of dub-off angle on chip evacuation in single-lip deep hole gun drilling". International Journal of Machine Tools \& Manufacture. 108 (2016): pp. 66-73.

5. Woona K.S., Tnayb G.L., Rahmana M., Wanc S., Yeod S.H. "A computational fluid dynamics (CFD) model for effective coolant application in deep hole gundrilling". International Journal of Machine Tools \& Manufacture. 113 (2017): pp. 10-18.

6. Biermann D., Kersting M., Kessler N. "Process adapted structure optimization of deep hole drilling tools". CIRP Annals Manufacturing Technology. 58 (2009): pp. 89-92.

Translation of scientific articles, their computer composition and publishing them on the website www.mechanik.media.pl by original articles in Polish is a task financed from the funds of the Ministry of Science and Higher Education designated for dissemination of science.

Ministry of Science and Higher Education

Republic of Poland 